Instructions for authors, subscriptions and further details:

http://qre.hipatiapress.com

\title{
A Teacher Questioning Activity: The Use of Oral Open-ended Questions in Mathematics Classroom
}

Mela Aziza ${ }^{1}$

1) Department of Tadris Matematika, Institut Agama Islam Negeri Bengkulu, Indonesia.

Date of publication: February $28^{\text {th }}, 2021$

Edition period: February 2021 - June 2021

To cite this article: Aziza, M. (2021). A Teacher Questioning Activity: The Use of Oral Open-ended Questions in Mathematics Classroom. Qualitative Research in Education, 10(1), 31-61. doi:10.17583/qre.2021.6475

To link this article: http://dx.doi.org/10.17583/qre.2021.6475

\section{PLEASE SCROLL DOWN FOR ARTICLE}

The terms and conditions of use are related to the Open Journal System and to Creative Commons Attribution License (CC-BY). 


\title{
A Teacher Questioning Activity: The Use of Oral Open-ended Questions in Mathematics Classroom
}

\author{
Mela Aziza
}

Institut Agama Islam Negeri Bengkulu

(Received: 26 August 2020; Accepted: 22 February 2021; Published: 28 February 2021)

\section{Abstract}

This research aims to analyse a teacher's questioning activity using oral open-ended questions in the mathematics classroom in three phases: the teacher asks open-ended mathematics questions orally, students answer the questions, and the teacher responds to the answers. This research involved a mathematics teacher and twenty-three year 7 students (aged eleven-twelve years old) in a secondary school in the UK. The samples were chosen using purposive sampling technique. The data collection technique used was three 45-minute-long lesson observations using field notes and audio-recordings. The notes and the transcript of the recording were analysed to find the answers for three research questions. The results showed that the teacher posed any kind of questions orally. The teacher asked two or three oral open-ended questions. Students answered those questions with different answer. The answers were not only correct, but also incorrect and incomplete. After getting an answer, the teacher responded by asking follow-up questions both closed and open-ended.

Keywords: questioning activity, open-ended questions, follow-up questions 


\section{Una Actividad de Preguntas para el Maestro: el Uso de Preguntas Abiertas Orales en el Aula de Matemáticas}

Mela Aziza

Institut Agama Islam Negeri Bengkulu

(Recibido: 26 de aosto de 2020; Aceptado: 22 de febrero de 2021; Publicado: 28 de febrero de 2021)

\section{Resumen}

Esta investigación tiene como objetivo analizar la actividad de cuestionamiento de un maestro utilizando preguntas abiertas orales en el aula de matemáticas en tres fases: el maestro hace preguntas matemáticas abiertas de manera oral, los estudiantes responden las preguntas y el maestro responde a las respuestas. Esta investigación involucró a un profesor de matemáticas y veintitrés estudiantes de séptimo año (de once a doce años) en una escuela secundaria en el Reino Unido. La muestra fue seleccionada mediante la técnica de muestreo intencional. La técnica de recolección de datos utilizada fue tres observaciones de lecciones de 45 minutos de duración utilizando notas de campo y grabaciones de audio. Se analizaron las notas y la transcripción de la grabación para encontrar las respuestas a tres preguntas de investigación. Los resultados mostraron que el profesor planteaba cualquier tipo de preguntas de forma oral. El maestro hizo dos o tres preguntas abiertas orales. Los estudiantes respondieron esas preguntas con una respuesta diferente. Sin embargo, las respuestas no solo fueron correctas, sino también incorrectas e incompletas. Después de obtener una respuesta, el maestro respondió haciendo preguntas de seguimiento tanto cerradas como abiertas.

Palabras clave: actividad de preguntas, preguntas abiertas, preguntas de seguimiento. 
questioning activity is an activity where a teacher asks questions in the classroom. It is pivotal and cannot be separated from teaching and learning activities because teachers spend the most time asking questions (Sullivan \& Lilburn, 2002). Teachers may ask questions either orally or in written form (Cotton, 2001). However, Cotton stated that during classroom recitations, oral questions are more effective for stimulating learning and teaching activities than written questions. Through oral questions, teachers can also motivate students to take part actively in the classroom discussion (Smith et al., 2006) and then bravely verbalise their ideas (Chin, 2007). Regarding questioning activity in the mathematics classroom, asking questions orally is likely to maximise the goals of the questions, such as, promoting students' independent thinking, involving students in an interactive learning process, as well as developing students' verbal communication (Shahrill, 2013). Heidari and Rajabi (2017) also found that oral questions have significant effects on the level of students' interest in mathematics. Although Heidari and Rajabi (2017) and Shahrill (2013) studied the effectiveness of verbal or oral questioning in mathematics classroom, they focused on all question types.

To maximise oral questioning activity, teachers should include appropriate higher-order questions (Shahrill, 2013), keeping in mind that some authors believe that higher-order questions refer to open-ended questions (Chin, 2006; Lee \& Kinzie, 2012; Tofade et al., 2013). Despite the fact that open-ended questions pose numerous benefits, some researchers (Al-Absi, 2012; Muir, 2009; Kwon et al., 2006) have found that teachers mostly ask closed questions during a mathematics lesson. They found out the teachers difficult to react to different possible responses from students when asking open-ended questions.

Based on the importance of asking open-ended questions orally above, it is required to look at back the extent to which previous research has been carried out. Some studies (Klavir and Hershkovitz, 2008; Yee, 2002; Absi, 2012) related to the use of open ended questions in the mathematics classroom have been done, but they analysed the students' answers to openended questions in written form (tasks or exercises). Thus, it will be required to investigate further how teachers ask open-ended questions orally in the mathematics classroom.

When asking questions, a teacher's main goal is to get students to answer the questions (Hufferd-Ackles et al., 2004). Students' answers are pivotal 
aspects because they will affect the level of the teacher's exploration of the problem (Pehkonen, 1999). After posing a question, a teacher will get students' answers and then s/he may respond to them (Chin, 2006). Openended questions challenge teachers in responding to students' unpredictable answers (Moyer \& Milewicz, 2002). Therefore, how students may answer oral open-ended questions and how teacher re-respond students' answers can be studied more deeply.

\section{Teachers' Open-Ended Questions}

\section{The Definition of Open-Ended Questions}

A question is a problem that requires to be answered. Most literature types questions according to the number of possible answers instead of the cognitive level of the questions (Kwon et al., 2006; Yee, 2002; Nohda, 2000; Pehkonen, 1999). Questions are categorised as closed questions if they have only one correct answer and as open-ended when they have more than one acceptable answer. Closed questions require memory-driven responses, while open-ended questions require deeper answers that produce more than known facts (Sullivan \& Lilburn, 2002). Generally, open-ended questions refer to questions that have more than one acceptable answer (Sullivan et al., 2000; Smith \& Higgins, 2006). Open-ended questions also link to different terms or activities, such as investigations in Britain, realistic mathematics in the Netherlands, and projects in Norway and Denmark (Pehkonen, 1997). Furthermore, open-ended questions are called incomplete or ill-structured problems because they allow different correct answers and mathematical ideas (Mihajlović \& Dejić, 2015). Meanwhile, Galton et al. (1999) defined an open-ended question to be one in which the teacher accepts more than one answer from students. However, there is a condition when the teacher asks a question allowing students give more than one answer but s/he only get an answer from one student. Hence, it may be better to look further at the definition of an open-ended question based on the question itself rather than the teacher's reaction.

In addition, Nohda (2000) defined three kinds of open-ended questions. These are "process is open"; "end products are open"; and "ways to develop are open" (p. 9). "Process is open" refers to a question that has multiple solution methods, "end products are open" means the question has more than 
one correct answer, and "ways to develop are open" means students are able to develop a new question after answering the original question. ,Mihajlović and Dejić, (2015) state that open-ended questions can be multiple-solution tasks that have several paths to find the answers. Furthermore, Schukajlow and Krug (2014) categorised multiple solutions into questions that can be solved through multiple solution methods, questions having multiple solutions/answers, and a combination of the first two categories (having multiple solution methods and answers). Hence, Schukajlow and Krug's second and the third categories can be included in open-ended questions because they have multiple correct answers, whereas the first category may only produce one correct answer. Thus, based on different perspectives (see Figure 1), I conclude that an open-ended question is a question that has more than one acceptable answer, can be solved through multiple solution methods, and can be developed into new questions.

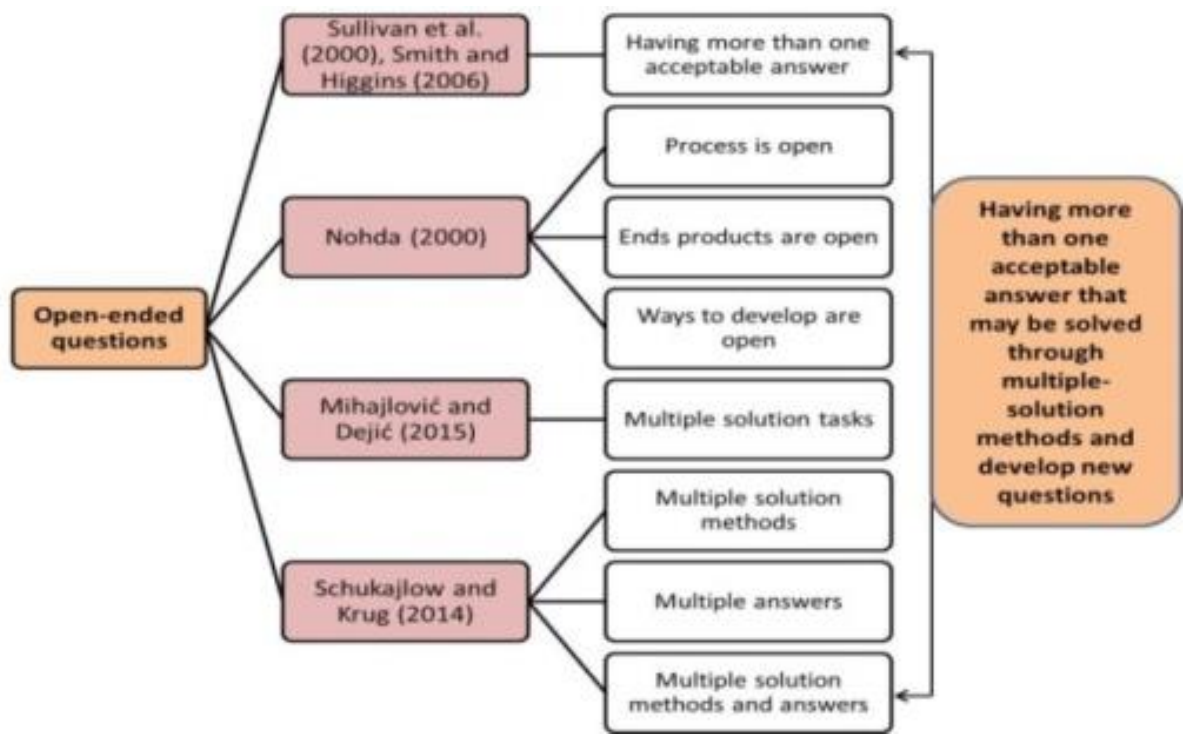

Figure 1. The definition of open-ended questions 


\section{The Types of Open-Ended Questions}

Open-ended questions can be divided into different types. Kwon et al. (2006) described seven types of open-ended questions: "overcoming fixation, multiple answers, multiple strategies, strategy investigation, problem posing, active inquiry tasks, and logical thinking" (p. 54). Kwon et al. categorise types of open-ended questions based on what questions teachers posed during their research. Hence, there are possibilities for other types of open-ended questions that can be developed with further research. Moreover, multiple answers and strategies may not be types of open-ended questions because they are common criteria for open-ended questions.

On the other hand, Pehkonen (1997) explained that open-ended questions consist of: "real-life situations (related to daily life), problem posing (finding or formulating a problem), investigations (doing activities based on given situations), projects (working a larger study independently), problem fields or sequences (a number of connected problems), problem variations ("whatif"-method), and problems without a question" (p. 9). In a similar vein, Yee (2002) divided open-ended questions into "real-life problems, problem posing, investigations and projects, problems to explain errors, as well as problems with missing data" (p.136). Yee (2002) and Pehkonen (1997) use the same four terms (real-life situations, problem posing, investigations, and projects). Furthermore, 'problems to explain errors' from Yee may represent 'problem sequences,' which is a collection of connected questions (Pehkonen, 1997), because teachers may use some related questions when asking students to analyse errors in the questions or answers. The 'problems with missing data' (Yee, 2002) can also refer to 'problem variations ("whatif'-method)' and 'problems without question' from Pehkonen (1997). Therefore, the types of open-ended questions from Yee may represent Pehkonen's.

On the other hand, Yee (2002) has not provided examples of all of his types of open-ended questions. Consequently, it may be difficult to differentiate between real-life situations, investigations, and projects. Based on my experience, teachers usually use real-life contexts and investigative methods when assigning a project. Hence, real-life situations and investigations may also be applied in students' projects. In addition, for me, not all of those open-ended question types can be asked in one lesson. For instance, based on my personal experience, students might spend a lot of time 
working on an investigation or a project because they have to analyse the assignment and find appropriate ways to finish it. Hence, from my perspective, some types of open-ended questions that may be asked in a lesson are real-life questions, problem-posing, questions to explain errors and questions with missing data.

\section{Students' Answers to Open-Ended Questions}

Muir (2009) divided students' answers into short answer, explanation, sharing, justification, and question or challenge. If students give a short response to the question using three words or less, this response would be called a short answer. The explanation is longer than a short answer, and it differs from sharing because students have to explain further their answer or strategy when giving an explanation. Justification refers an answer in which students can generalise an idea. Lastly, when students question or contest the answer, this response would be put in the question or challenge category. Students' answers in the form of explanation and/or justification are closely related to the development of mathematical ideas, communications, problem solving and reasoning skills (Rosli et al., 2014), while Tanner et al. (2005) found that the majority of students' answers to questions are very short, i.e., they involve only three or fewer words. Hence, it is suggested that teachers pose questions that can produce longer answers.

Teachers may receive different answers from students regarding closed and open-ended questions. Closed questions will produce short answers that can be easily justified for correctness (Chin, 2006) and are usually related to recall or the lower-order cognitive level (Chin, 2007). Meanwhile, Muir (2009) found that open-ended questions produce more explanations than other types of questions. Furthermore, teachers are able to detect students' errors and misconceptions through open-ended questions since they are used not only for getting correct answers, but also for encouraging students to criticise and explain the reasons behind their answers, as well as the strategy applied (Cai, 1997). Similarly, Lee and Kinzie (2012) also found that the majority of students respond to open-ended questions by giving predictions and reasoning. Prediction encourages students to form a conjecture based on their observations, whereas reasoning helps them find the causes behind the answer. As a result, Lee and Kinzie conclude that students use a high level of cognition in response to open-ended questions, i.e., questions in which 
they give not only short responses, but also more complex answers that can create a discussion. Thus, students are likely to answer closed questions with short answers, while they may provide explanations and justifications with their answers to open-ended questions.

Students may give both correct and incorrect answers to open-ended questions (Clarke et al., 1992; Sullivan et al., 2000; Klavir \& Hershkovitz, 2008; Franke et al., 2009). During the solving process for open-ended questions, teachers are not only concerned with the correctness of the answer, but also with the reasons behind mathematical thinking, solution methods, and misconceptions (Klavir \& Hershkovitz, 2008; Franke et al., 2009). Therefore, Klavir and Hershkovitz (2008) have categories for analysing students' answers to open-ended questions beyond correct and incorrect answers. These are "inappropriate solutions (solutions that do not meet the conditions asked by the questions) and unintelligible solutions (frequently due to illegible handwriting)" (p. 3). Besides paying attention to the correctness of answers given, Franke et al. (2009) also defined students' answers as correct and complete (the answer is correct, and the explanation is complete), ambiguous or incomplete (the answer is correct but uses an incomplete explanation), and incorrect (both an incorrect answer, and an incomplete explanation). It seems that while asking an open-ended question, a teacher does not stop at the answer but also seeks how the answer is found.

\section{Teachers' Responses to Students' Answers}

After posing a question, a teacher will get students' answers and then s/he may respond to them (Chin, 2006). However, open-ended questions challenge teachers in responding to students' unpredictable answers (Moyer \& Milewicz, 2002). Despite this fact, Schuster and Anderson (2005) state that teachers can anticipate the unpredictable answers by thinking through the possible answers to the question, then deciding how to react to the answers. Teachers still cannot predict precisely what will happen before they ask the questions directly to students. When working with open-ended questions, Pehkonen and Ejersbo (2005) stated that teachers have to make quick decisions related to: "Will he accept or reject students' ideas and why?; How can he prepare himself?; What kind of answers can he expect?; How can he in the situation concentrate on his next move in the classroom situation?" (p. 877). Therefore, teachers have to be confident in their 
knowledge so that they know whether they will praise, criticise, or accept a student's answer, as well as what they will do next after listening to the student's answer (Smith et al., 2006).

During a questioning activity, both correct and incorrect answers are important (Tofade et al., 2013). Hence, teachers have to be more open in responding to students' correct or incorrect answers (Shahrill, 2013). Gall and Rhody (1987) state that a teacher is able to reinforce a student's correct answer by praising or acknowledging it, while if the answer is incorrect, the teacher has to re-teach it or explore the answer further. Furthermore, Tofade et al. (2013) pointed out that in response to a correct answer, teachers can affirm the answer, reinforce it, then move to further questions, or accept the answer and then ask other related questions that can build students' concepts. Meanwhile, in response to an incorrect answer, Tofade et al. suggest that teachers give corrective feedback by correcting the answer explicitly or providing comments, then ask another challenging question. Thus, incorrect answers can be used to stimulate students' explanations and justifications in the mathematics classroom (Hoffman et al., 2009).

When asking open-ended questions, teachers are encouraged to be more concerned with the process of finding the answer than with just the correctness of the answer (Cai, 1997). They should give feedback for every answer in order to promote an effective questioning activity (Smith \& Higgins, 2006). After getting students' answers, teachers are able to provide feedback by asking follow-up questions based on their answers (Graciano, 1998). Despite of using follow-up questions largely for incorrect answers, teachers can ask follow-up questions for both correct and incorrect answers to developing students' critical thinking (Moyer \& Milewicz, 2002). Followup questions can improve students' weak responses, build a rich discussion, foster students' curiosity and inquiry, and guide student in learning problemsolving skills (Gall, 1970). For instance, teachers can use follow-up questions in response to unpredictable answers to open-ended questions in order to create rich conversation in the classroom (Graciano, 1998) or develop a new activity (Smith \& Higgins, 2006). Thus, it appears that feedback or followup questions are likely to maximise the use of open-ended questions during a classroom discussion. Thus, Wells (1999) stated that asking an open-ended question result in students' participation, but, without effective feedback, teachers cannot guarantee the formation of an interactive learning environment. 
Regarding the way teachers ask follow-up questions, Smith et al. (2006) and Muir (2009) explained that after listening to a student's answer, a teacher can ask probe questions (the teacher stays with the same student to ask further questions) and uptake questions (the teacher incorporates a student's answer into subsequent questions). Graciano (1998) explained further that uptake questions can be considered high-level evaluations because they incorporate students' answers into a new question. Therefore, teachers may have different considerations in how to ask follow-up questions.

From those literature studies, I developed this below framework for this research.

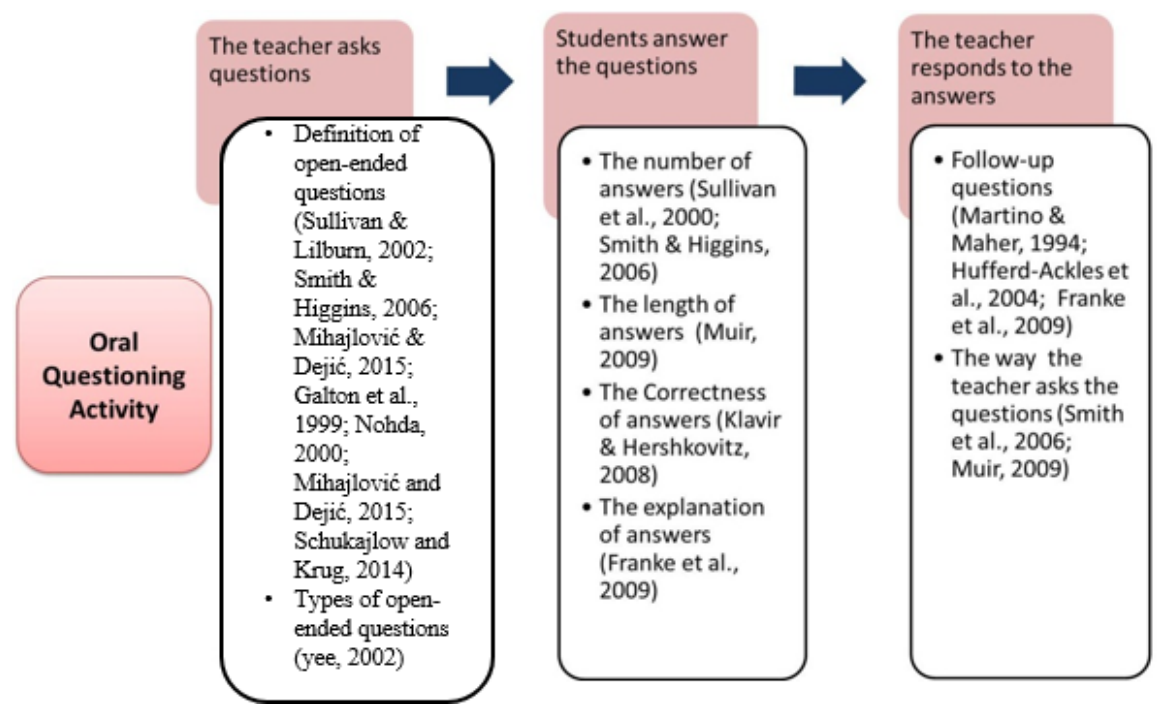

Figure 2. A framework of a teacher's oral questioning activity

Method

I have designed a research methodology for collecting data and then analysing it in order to answer my research questions. I carried out qualitative research because it allowed me to obtain a deep understanding of the teacher's questioning activity in description form (Bogdan \& Bilken, 1992; Savenye \& Robinson, 1996). In order to investigate directly questioning activity, I would go to the teacher's natural setting (Bogdan \& Bilken, 1992). 
I used lesson observations in the mathematics classroom for collecting the data. I would also be a nonparticipant observer, i.e., I would not interact with the participants whom I observed (Savenye \& Robinson, 1996). Regarding research sampling in qualitative research, Savenye and Robinson (1996) stated that researchers often use purposive samples to answer their research questions. Thus, I chose a mathematics teacher who might ask open-ended questions orally and his twenty-three Year 7 class (students aged eleventwelve years) in a secondary school in Bristol, UK. After obtaining access to the school from my supervisor, then I wrote research ethics form, participant information sheet, and participant consent form as the requirement for doing research.

The data were collected in 2017, from June 22nd until July $17^{\text {th }}$ using three 45-minute-long lesson observations of the teacher and students. During the observation, I took field notes descriptively using a format that has been consulted with the supervisor. These field notes were used to obtain data related to the time and date of observation as well as what the teacher did regarding the teacher's questioning strategy, the types of open-ended questions used, students' answers, and the teacher's responses to the students' answers over the course of the entire lesson. In addition, I gave the teacher a tape recorder to carry with him during lessons. He would be responsible for it since he was likely to approach the students when asking questions. I also recorded the lessons using a second recorder that I put in the back corner of the classroom. I was only human and could not record everything using field notes, so the audio tape could confirm and augmented my field notes. The recording was transcribed by matching the field notes and reconfirming with the teacher when there were doubts regarding the results of the transcript.

The data from the field notes and the transcribed audio recording would be analysed qualitatively using the framework that I developed (see Figure 2) to answer research questions: how the teacher asked open-ended questions orally, how students answered, how the teacher responded and followed-up students' answers. Data analysis was carried out in the following stages:

a) The data analysis was done for three days observation

b) All of open-ended questions found from the field notes and the transcribed audio recording were written down based on the definition of open-ended questions 
c) Each question was coded respectively with Q and a number from the first until the last day observation

d) The type of open-ended questions were categorized based on the type of questions from Yee (2002)

e) The teacher and students were given pseudonyms

f) Students' answers for every questions were written down and coded respectively with $\mathrm{Q}$ and $\mathrm{A}$ as well as a number

g) The anwers obtained for every questions were counted

h) The length of answers was categorized based on Muir (2009) and the correctness of answers was analysed using Klavir \& Hershkovitz (2008) and Franke et al. (2009).

i) What and how follow-up questions asked were analysed using theoretical framework on Figure 2.

j) Finally, the summary was written down.

\section{Results}

Despite the fact that the teacher addressed different mathematical topics in each lesson (patterns and sequences, multiplication, as well as number systems), he used a consistent questioning strategy. He asked an oral openended question, the students answered it, and the teacher responded to the answer. These three activities will be described below and supported by short transcripts as evidence.

\section{The Teacher Asked Open-Ended Questions Orally}

When asking open-ended questions, the teacher used different types of openended questions. I found that the teacher posed two or three oral open-ended questions during each 45-minute lesson. The teacher also developed these questions into further questions. I expound on this in 'the teacher responded to the answers' section. Table 1 below lists the teacher' oral open-ended questions. 
Table 1.

The open-ended questions asked orally

\section{Day Question \\ The teacher's oral open-ended questions \\ (Q)}

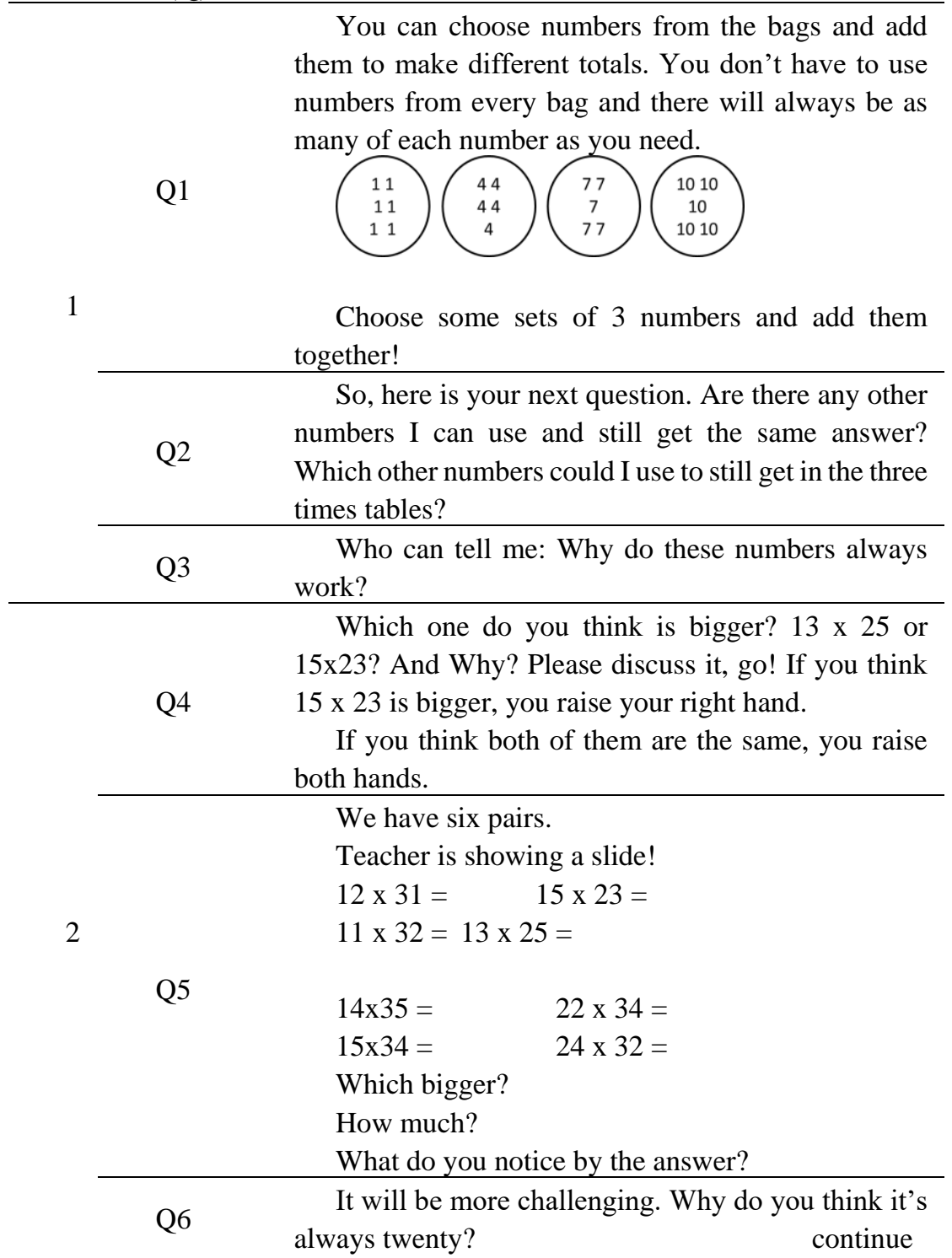


Table 1.

The open-ended questions asked orally (continuation)

We will do what a computer is based on. Anytime we take a picture and then send it on Facebook, So,

$3 \quad$ Q7 what is the message?

Now, we should begin with these questions!

What is the name of number system that we use?

Why do we use it?

Q8

Can you give me examples of Roman numerals?

I defined all the questions in Table 1 as open-ended questions in which students were allowed to give more than one answer, but not all of them fit within my framework (see Figure 1), which was based on Yee (2002). According to Yee, question 1 (Q1) can be categorised as an open-ended problem-posing question because students were able to create their own questions based on the data that the teacher gave. Meanwhile, other questions were used by the teacher to ask students to analyse. These include: Which other numbers could I use? (Q2); Which one? (Q4); What do you notice? (Q5); and Can you give me an example? (Q8). Through these questions, the teacher could also encourage students to find a conclusion or pattern. In addition, he posed open-ended questions to elicit different reasons from students for what they had found. These were questions question like: Why do these numbers always work? (Q3); Why do you think it's always twenty? (Q6); and Why do we use it? (Q7). Hence, I found that the main focus in asking an open-ended question orally should be how the question can stimulate students' different answers and not on the type of the open-ended question itself.

\section{Students Answered the Questions}

After the teacher orally asked an open-ended question, students would also answer it orally. I will describe how students answered those questions in terms of the number, length, and correctness of answers. 


\section{The number of answers}

From the observations, I found that students gave more than one answer for every open-ended question (Q) asked orally by the teacher. Table 2 below provides the number of answers for every question $(\mathrm{Q})$ that was mentioned in Table 1. 
Table 2.

Students' answers to every oral open-ended question

\begin{tabular}{|c|c|c|}
\hline $\begin{array}{l}\text { Question } \\
(\mathbf{Q})\end{array}$ & Students' answers & $\begin{array}{l}\text { Answer } \\
\text { (A) }\end{array}$ \\
\hline \multirow[t]{4}{*}{ Q1 } & $\mathrm{L}: 1+1+1=3$ & Q1A1 \\
\hline & $\mathrm{K}: 10+4+7=21$ & Q1A2 \\
\hline & $\mathrm{T}: 7+1+1=9$ & Q1A3 \\
\hline & $\mathrm{N}: 7+7+7=21$ & Q1A4 \\
\hline \multirow[t]{6}{*}{ Q2 } & B: 4 & Q2A1 \\
\hline & $\mathrm{C}: 5$ & Q2A2 \\
\hline & D: 19 & Q2A3 \\
\hline & $\mathrm{K}: 16$ & Q2A4 \\
\hline & G: 22,25 & Q2A5 \\
\hline & S: 28 & Q2A6 \\
\hline \multirow[t]{2}{*}{ Q3 } & E: There is different 3 in between them & Q3A1 \\
\hline & $\mathrm{H}$ : Because that is in a category $3 n+1$ & Q3A2 \\
\hline Q4 & $\begin{array}{l}\text { Some students raise right hand and } \\
\text { others raise both hands }\end{array}$ & $\begin{array}{l}\text { Q4A1 } \\
\text { O4A2 }\end{array}$ \\
\hline \multirow[t]{2}{*}{ Q5 } & K: Ehmm, they all are more than a hundred & Q5A1 \\
\hline & $\mathrm{N}$ : They all have a difference of twenty & Q5A2 \\
\hline \multirow[t]{2}{*}{ Q6 } & $\begin{array}{l}\text { E: Because if you look at the tens, there is always } \\
\text { like two tips looking away from the tens. }\end{array}$ & Q6A1 \\
\hline & $\begin{array}{l}\text { S: The difference of } 10 \text { and } 30 \text { is } 20 \text { and the } \\
\text { difference of } 2 \text { and } 1 \text { is } 1\end{array}$ & Q6A2 \\
\hline \multirow{3}{*}{ Q7 } & $\mathrm{J}$ : Is it $0,1,0,1 ?$ & Q7A1 \\
\hline & Teacher: That's binary system & \\
\hline & D: 10 & Q7A2 \\
\hline \multirow[t]{5}{*}{ Q8 } & $\mathrm{R}: \mathrm{X}$ & Q8A1 \\
\hline & $\mathrm{H}: \mathrm{I}$ is 1 & Q8A2 \\
\hline & $\mathrm{J}: \mathrm{V}$ is 5 & Q8A3 \\
\hline & $\mathrm{K}: \mathrm{XI}$ & Q8A4 \\
\hline & L: IX is 9 & Q8A5 \\
\hline
\end{tabular}

However, not all possible answers were discussed due to limited time or the teacher himself determining the number of answers that he wanted. For 
example, students were likely to give more different answers for Q1, but the teacher only asked for four answers (Q1A1, Q1A2, Q1A3, and Q1A4).

Teacher: We have many different solutions, but can you give me just four solutions!

Therefore, every open-ended question from Table 1 might produce more answers than those given in Table 2.

\section{The length of answers}

Based on Table 2, I found that the students' answers can be catagorised as short answer, explanation, justification, or question. Most of the students' answers for Q1, Q2, and Q8 were short answers because students only had to give one appropriate operation or number to answer the question. Meanwhile, when the teacher asked open-ended questions using 'why?' for Q3 and Q6, students gave longer answers (Q3A1, Q3A2, Q6A1, and Q6A2), in which they provided explanations about their reasoning. For Q4 and Q5, students were likely to justify some facts and then generalise an idea to find a conclusion (Q4A1, Q4A2, Q5A1, and Q5A2). Meanwhile, student $J$ responded to Q7 by questioning his answer to the teacher (Q7A1) so that the teacher had to reassure him that his answer was acceptable.

\section{The correctness of answers}

The correctness of the answers can be seen from the teacher's statements. When the teacher asked Q3 and found that the answers (Q3A1 and Q3A2) were correct, he emphasised and praised them. This is evident from the short transcript below:

Teacher: Who can tell me, why do these numbers always work? (Q3)

$\mathrm{E}$ : There is a difference of 3 in between them. (Q3A1)

Teacher: There is a difference of 3 in between them. It's the first reason.

$\mathrm{H}$ : Because that is in a category $3 \mathrm{n}+1$. (Q3A2)

Teacher: Oh, that's really good shoot. 
Meanwhile, if the answer was incorrect, the teacher would make different statements. For example, when he posed Q2 and got incorrect answers (Q2A1 and Q2A2), he responded as seen below:

Teacher: Which other numbers could I use to still get in the three times tables?(Q2)

B: 4. $(Q 2 A 1)$

Teacher: Four is ready got $B$.

C: 5. (Q2A2)

Teacher: No, five is not gonna work.

D: 19.

Teacher: We can use 19.

When a student gave an incomplete answer (for example, Q7A2), the teacher added information to complete it.

Teacher: D, Do you know what the number system we use is called?

(Q7)

D: 10. (Q7A2)

Teacher: Yes 10. We call it a base- 10 number system because we have ten digits, 0 to 9.

\section{The Teacher Responded to the Answers}

\section{The teacher's follow-up questions}

The teacher responded to students' answers differently based on the correctness of the answers. When the teacher posed Q5 and stated that the student's answer (Q5A1) was correct, he asked another answer without asking follow-up questions.

Teacher: OK, I wanna go to K. What do you notice from these answers? (Q5)

$\mathrm{K}$ : Ehmm... they all are more than a hundred (Q5A1)

Teacher: Ok that's true. Go to N?

When he did not state whether the answer was correct or not, the teacher posed some additional or follow-up questions in order to develop students' 
understanding or ideas. While discussing the answers for $\mathrm{Q} 4$, the teacher asked further questions (Q4A1 and Q4A2).

Teacher: Which one do you think is bigger? $13 \times 25$ or $15 \times 23$ ? And Why? Please discuss it. Go! (Q4)

Teacher: There are a few people say the same and others say the right is bigger. (Q4A1 and Q4A2)

Teacher: D, why do you think they're the same?

D: You just put two more and two less.

Teacher: So, what do you say?

D: They have two differences, 13 and 15, 25 and 23.

Teacher: $\mathrm{C}$, why do said the right is bigger?

$\mathrm{C}$ : Because the estimate for $15 \times 23$ is bigger than $13 \times 25$.

From Q5, the teacher also developed some follow-up questions from a correct answer (Q5A2).

Teacher: OK, I wanna go to $\mathrm{K}$. What do you notice from these answers? (Q5)

Teacher: Go to N?

$\mathrm{N}$ : They all have a difference of twenty. (Q5A2)

Teacher: Wait! Are they all even numbers?

Students: No.

Teacher: OK, so, the other one is which number is always bigger in each case?

Teacher: A, in each case, which one gives me the bigger answer?

A: The one gives a bigger number at the first.

Meanwhile, he provided feedback, like a clue, for students when he received incorrect answers to questions. For example, when he asked Q2, he got a student's incorrect answer (Q2A1) and went from there:

Teacher: Which other numbers could I use to still get in the three times tables?(Q2)

B: Four. (Q2A1)

Teacher: Four already got B. I wanna give you one example.

Teacher: If 13 is gonna work, what other numbers might work? 
Furthermore, he would give an evaluation in the form proof that the answer was incorrect, then asked a further question, as shown when the teacher asked Q6 and a student gave an answer (Q6A1):

Teacher: Why do you think it's always twenty? (Q6)

Teacher: Ok, E?

$\mathrm{E}$ : Because if you look at the tens, there is always like two tips looking away from the tens. (Q6A1)

Teacher: Oh you say it because it's 10 and 30, 10 and 30, 10 and 30, 10 and 30, 20 and 40, Oh it doesn't fit with the pattern. Yes, S?

$\mathrm{S}$ : The difference of 10 and 30 is 20 and the difference of 2 and 1 is 1.

Teacher: Ok, we got a difference of 20 between 20 and 40 and one between 5 and 6 . Then when we multiply the difference of 20 and the difference of 1 , we got 20

So, because of that, they always have the difference of 20 .

Teacher: So, we will try one. Let's see if it will work. 45 x 66 and $46 \times 65$ ?

Thus, it seems that the teacher was not only concerned about the correctness of students' answers, but also about helping students understand their mistakes by giving feedback or evaluation before he asked follow-up questions.

In addition, the teacher specifically asked additional questions for Q8 to encourage a student to complete his answer (Q8A1).

Teacher: R, Can you give me examples of Roman numerals? (Q8)

$R: X .(Q 8 A 1)$

Teacher: X means what?

R: Ten

From all the follow-up questions that the teacher used during his questioning activities, it can also be seen that the follow-ups could be openended or closed. The teacher used closed follow-up questions to focus on the clarity and completeness of the answer. For example: How much bigger is it? Are they all even numbers? X means what?; XI would be?; Does it say we have to use one of each?; and How many n?. Meanwhile, he would ask open-ended follow-up questions using 'How?' and 'Why?' to stimulate 
students' thoughts on explanations and reasoning and give them deep understanding. Hence, the teacher optimised the questioning activity by asking both open and closed follow-up questions.

\section{The way the teacher asked follow-up questions}

The teacher asked follow-up questions by posing follow-up probe questions of the same student. In the transcript below, the teacher tried to encourage Student $K$ to complete and elaborate on his answer (Q8A4) the way the teacher asked follow-up questions, he posed probe questions in which the teacher stayed asking further questions to the same student. From this transcript below, the teacher tried to encourage the student $K$ to complete and elaborate his answer (Q8A4) more deeply.

Teacher: R, Can you give me examples of Roman numerals? (Q8)

K: XI. (Q8A4)

Teacher: XI would be?

$\mathrm{K}: 11$.

Teacher: Why?

$\mathrm{K}$ : It's ten and one.

The teacher also asked uptake questions (incorporating a student's answer into subsequent questions) of the students, as shown below:

Teacher: Why do these numbers always work? (Q3)

$\mathrm{H}$ : Because that is in a category $3 \mathrm{n}+1$. (Q3A2)

Teacher: Oh, that's really good shoot.

Teacher: We have $3 n+1$ is $1,4,7$, and 10 . So we have $3 n$ in the sequence: $0,3,6$, and 9. So, we have a lot of $3(3 n+1)$.

Teacher: Who remembers how to solve the bracket for me? $\mathrm{S}$, Go for it!

S: 9 n adds 3.

Teacher: Perfect!

Teacher: Now, why do you think it is always to be in the three times tables of algebra?

Teacher: B?

B: Because it's three.

Teacher: Because that's three. What else is in this B? 
B: n.

Teacher: How many n?

F: Uhm, 9 is in three times tables.

Teacher: Right!

In summary, I analysed the data using my framework (see Figure 2) in order to answer my research questions. I found some new points to consider that were not part of my original framework. My findings can be seen in Figure 3 below:

\begin{tabular}{|c|c|c|}
\hline $\begin{array}{l}\text { The teacher asked open- } \\
\text { ended questions orally } \\
\text { The types of open-ended } \\
\text { questions } \\
\text { Problem-posing } \\
\text { (asking students to } \\
\text { create a question) } \\
\text { All questions that } \\
\text { allow students to give } \\
\text { more than one } \\
\text { answer }\end{array}$ & 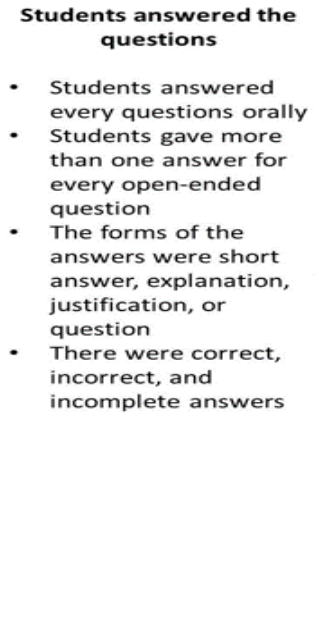 & $\begin{array}{l}\text { The teacher responded } \\
\text { to the answers } \\
\text { The teacher asked } \\
\text { follow-up questions } \\
\text { of both correct and } \\
\text { incorrect answers to } \\
\text { promote deep } \\
\text { understanding, but } \\
\text { he first gave } \\
\text { feedback/evaluation } \\
\text { so students could } \\
\text { realise their mistakes. } \\
\text { He asked specific } \\
\text { questions to } \\
\text { complete the } \\
\text { answers. } \\
\text { The teacher's follow- } \\
\text { up questions were } \\
\text { open-ended and } \\
\text { closed questions } \\
\text { The teacher used } \\
\text { probing and uptake } \\
\text { questions when } \\
\text { asking follow-up } \\
\text { questions }\end{array}$ \\
\hline
\end{tabular}

Figure 3. The summary of findings related to the use of oral open-ended questions

\section{Discussion}

\section{Maximising the Use of Oral Open-ended Questions}

After observing three lessons in a Year 7 class (aged eleven-twelve years old), I found that the teacher asked questions orally throughout the entire lesson. These oral questions included open-ended questions. Through asking oral questions, the teacher created a rich classroom discussion and encouraged students to verbalise their ideas. Although the teacher orally asked both closed and open-ended questions, he used open-ended questions 
not only for fostering students' verbal communication skills, but also for developing their mathematical thinking and reasoning. This is in line with the expected goals of learning mathematics (NCTM, 2000). The potential of using open-ended questions in the mathematics classroom has been discussed by Shahrill (2013), Chin (2007), Kwon et al. (2006), and Smith et al. (2006), but they have not examined specifically the use of oral open-ended questions in the mathematics classroom. Hence, the findings from this study show that the teacher is able to optimise students' mathematics skills by asking openended questions orally in the classroom.

The teacher's questioning activity consisted of the teacher asking questions, students answered the questions, and then the teacher responding to the answers. While asking oral open-ended questions, he occasionally used a slide projected onto an interactive whiteboard, but especially when he needed to provide images related to the question. As a result, he did not need to spend much time writing or drawing on the whiteboard. In contrast, not all schools provide advanced technology to support learning and teaching. Occasionally, mathematics teachers are also not able to use the technology well. When either of these happens, they may be considered obstacles for a teacher trying to ask oral mathematics questions about topics that require representations like symbols and images. Therefore, technology and the ability of teachers to use it are pivotal in learning mathematics (Muhtadi, Kartasasmita, \& Prahmana, 2017).

Teachers may consider asking open-ended questions to develop students' problem solving, reasoning, and communication skills (Kwon et al. 2006). There are also different types of open-ended questions that they can ask (Yee, 2002). However, the most important point in asking open-ended questions is allowing students to give more than one answer, regardless of the type of open-ended question. Although the teacher asked an open-ended problemposing question Q1 (Yee, 2002), he posed most of the open-ended questions (Table 1) using 'Why?' and 'What do you notice?' in which they cannot be categorised by Yee. Therefore, when I included only the types of open-ended questions from Yee (2002) in the framework that I developed (Figure 2), I may not have come up with a framework that will be able to analyse every possible open-ended question that the teacher asked orally. Thus, when analysing type of open-ended questions, it may be better to go back to the general meaning of open-ended questions (Figure 1). 


\section{The Development of Students' Answers into a Rich Discussion}

Students gave more than one answer for every oral open-ended question (Table 2), but the teacher was not able to elicit all possible answers from students. While the teacher orally asked open-ended questions, he would also ask students to answer orally. Consequently, if he asked for every possible answer, it would take too much time. This can be seen as a weakness in asking oral open-ended questions.

Unlike closed questions, open-ended questions have huge potential for developing longer answers (Muir, 2009). This potential was also born out in my research. Although I argue that longer answers is not always better, students in my study answered most of the teacher's questions (Table 1) not only with long answers but also provided reasoning, explanation, and justification (Table 2), especially when the teacher asked 'Why?' and 'What do you notice?' (Q3, Q4, Q5, Q6, Q7). The cognitive levels reasoning, explanation, and justification closely link to analysis, synthesis, and evaluation levels. Therefore, open-ended questions can be categorised as higher-cognitive questions (Chin, 2006; Lee \& Kinzie, 2012; Tofade et al., 2013) that can foster students' critical thinking skills. Furthermore, students could answer some open-ended questions with short answers (Q1, Q2 and Q8). The teacher could extend the answer by using follow-up questions. Thus, the method a teacher uses to follow up a student's answer can help to maximise the answer itself.

It was also found that students gave not only correct answers, but also incorrect and incomplete answers to the teacher's oral open-ended questions (Table 2). This supports previous research (Franke et al., 2009) that says that students' answers to open- ended questions may be correct, ambiguous or incomplete, or incorrect. The correctness and completeness of the answers was indicated by how the teacher responded to the answers. He would praise correct answers (Gall \& Rhody, 1987), provide corrective feedback for incorrect ones (Tofade et al., 2013), and ask a specific question for incomplete answers (Franke et al., 2009). However, when discussing the answers, students were not encouraged to evaluate/criticise others' ideas. Through this method, the teacher was able to build a rich discussion of the answers given. It may also be the reason why Chin (2007) suggested that teachers involve students in evaluating and judging the correctness of the answer. 
In responding students' answers, the teacher would ask follow-up questions, but when he got a correct answer, the teacher would praise it quickly to emphasise that it was correct. Otherwise, he would ask follow-up questions to develop students' thinking and reasoning. When given incorrect answers, the teacher preferred to give clues, corrective feedback, or evaluation before asking follow-up questions. This is what Tofade et al. (2013) recommended that teachers do in their questioning activities. The feedback that the teacher gave through the classroom discussion can make students aware of their mistakes so that they will not repeat the same mistakes in the future. Finally, when given an incomplete answer, the teacher asked a specific question to encourage students to complete it. This supports the findings of Franke et al. (2009), who found that specific questions can be used to elaborate students' explanations and clarify incomplete answers. Hence, the teacher's responses to students' answers are likely to influence the development and depth of the answers.

When asking follow-up questions, a teacher could develop oral openended questions further into closed and open-ended follow-up questions. Closed questions are used for recalling known facts while open-ended questions can be used to make students analyse and criticise a problem (Sullivan \& Lilburn, 2002). In this study, both closed and open questions had significant roles as follow-up questions in order to optimise students' unpredictable answers to open-ended questions and create a rich classroom discussion like Graciano (1998) found in his study. Meanwhile, when the teacher posed open-ended follow-up questions like 'Why?' and 'How?', students were encouraged to give more explanatory answers, just as found by Hufferd-Ackles et al. (2004). Consequently, students will learn to communicate their mathematical ideas and then convince others of those ideas (Martino \& Maher, 1994). The teacher asked follow-up questions by asking further questions of the same student (probe questions) in order to understand and explore the student's thinking, just as Franke et al (2009) found in their study. He also posed uptake questions. He incorporated a student's answer into subsequent questions to extend the answer and deepen students' understanding. Thus, to optimise students' answers, a teacher should be able to develop different follow-up question types and then ask them in different ways. A teacher has to consider not asking too many questions in the classroom in order to prevent his dominant participation. 
Students should be encouraged participate more in asking questions to the teacher to create balance in the learning process (Gong and Yanchar, 2019).

\section{Conclusion}

The teachers have asked some open-ended questions orally. However, the fact that this study cannot categorise every one of this successful teacher's questions using Yee's types of open-ended questions made researcher reconsiders the meaning of open-ended questions themselves (having more than one acceptable answer, may be solved through multiple solution methods, and developed new questions). From this study, it can be seen that using open-ended questions orally can enrich students' mathematics skills like mathematical creativity and communication primarily when they gave different responses to every question. Furthermore, students' participation became increased. When the teacher posed an oral open-ened question, some students tried to answer it. Teachers can also use follow-up questions for clarifiying students' answers, encouraging students to think critically, as well as developing the deep of students' responses regarding a mathematics problem. Therefore, this study helped teachers to know the usefulness of oral open-ended questions, to understand how to optimise asking the questions orally, and to analyse the use of oral open-ended questions in the mathematics classroom. Researchers can also reflect on the way to do study related to questioning activity in which they are expected to focus on all the types of questions, the way teachers ask, students' possible answers, and follow-up the answers.

There are some limitations to this study in which it involved only one mathematics teacher as the sample. This means that the findings may not be appropriate for other teachers in different settings. This study also did not take differences in mathematical topics into account when analysing the possible types of open-ended questions. It also has not investigated the teacher's perspective towards asking open-ended questions orally. Furthermore, the findings can be useful for other mathematics teachers and researchers as reflection for their future teaching and research. 


\section{References}

Al-Absi, M. (2012). The Effect of Open-ended Tasks-as an assessment tool on Fourth Graders' Mathematics Achievement, and Assessing Students Perspectives about it. Jordan journal of educational sciences, 9(3), 345-351.

http://repository.yu.edu.jo/bitstream/123456789/3836/1/604899.pdf

Bogdan, R. C., \& Bilken, S. K. (1992). Qualitative research for education: An introduction to theories and methods. Foundations of Qualitative research for Education, 1-11.

Cai, J. (1997). Beyond Computation and Correctness: Contributions of Open-Ended Tasks in Examining US and Chinese Students' Mathematical Performance. Educational Measurement: Issues and Practice, 16(1), 5-11.

Chin, C. (2006). Classroom interaction in science: Teacher questioning and feedback to students' responses. International journal of science education, 28(11), 1315-1346.

https://doi.org/10.1080/09500690600621100

Chin, C. (2007). Teacher questioning in science classrooms: Approaches that stimulate productive thinking. Journal of Research in Science Teaching, 44(6), 815-843. https://doi.org/10.1002/tea.20171

Clarke, D. J., Sullivan, P., \& Spandel, U. (1992). Student response characteristics to open-ended tasks in mathematical and other academic contexts. The Centre.

Cotton, K. (2001). Classroom questioning. School improvement research series, 3 .

http://www.learner.org/workshops/socialstudies/pdf/session6/6.Class roomQuestioning.pdf

Franke, M. L., Webb, N. M., Chan, A. G., Ing, M., Freund, D., \& Battey, D. (2009). Teacher questioning to elicit students' mathematical thinking in elementary school classrooms. Journal of Teacher

Education, 60(4), 380-392.

https://doi.org/10.1177/0022487109339906

Gall, M. D. (1970). The use of questions in teaching. Review of educational research, 40(5), 707-721. https://doi.org/10.3102/00346543040005707 
Gall, M. D., \& Rhody, T. (1987). Review of research on questioning techniques. Questions, questioning techniques, and effective teaching, 23-48.

Galton, M., Hargreaves, L., Comber, C., Wall, D. \& Pell, T. (1999) Inside the primary classroom-20 years on. London: Routledge.

Gong, S. P., \& Yanchar, S. C. (2019). Question asking and the common good: a hermeneutic investigation of student questioning in moral configurations of classroom Practice. Qualitative Research in Education, 8(3), 248-275. https://doi.org/10.17583/qre.2019.3947

Graciano, M. K. (1998). Creating authentic conversation in literature discussion: the role of teacher feedback. DOCUMENT RESUME, 56.

Heidari, R., \& Rajabi, F. (2017). Effectiveness of the Method of Designing Classroom Oral Questioning on the Learning of Mathematics and Students's Interest in this Course. American Journal of Mathematics and Statistics, 7(1), 44-49.

https://www.semanticscholar.org/paper/Effectiveness-of-the-Methodof-Designing-Classroom-Heidari-

Rajabi/c91287e706fb520c17a2abf7ca7ea06e63b70605\#paper-header

Hoffman, B. L., Breyfogle, M. L., \& Dressler, J. A. (2009). The Power of Incorrect Answers. Mathematics Teaching in the Middle School, 15(4), 232-238. https://doi.org/10.5951/MTMS.15.4.0232

Hufferd-Ackles, K., Fuson, K. C., \& Sherin, M. G. (2004). Describing levels and components of a math-talk learning community. Journal for research in mathematics education, 81-116. https://doi.org/10.2307/30034933

Klavir, R., \& Hershkovitz, S. (2008). Teaching and evaluating 'openended'problems. International Journal for Mathematics Teaching and Learning, 20(5), 23. https://doi.org/10.1.1.459.7430

Kwon, O. N., Park, J. H., \& Park, J. S. (2006). Cultivating divergent thinking in mathematics through an open-ended approach. Asia Pacific Education Review, 7(1), 51-61. https://doi.org/10.1007/BF03036784

Lee, Y., \& Kinzie, M. B. (2012). Teacher question and student response with regard to cognition and language use. Instructional Science, 40(6), 857-874. https://doi.org/10.1007/s11251-011-9193-2 
Martino, A. M., \& Maher, C. A. (1994). Teacher Questioning To Stimulate Justification and Generalization in Mathematics. http://files.eric.ed.gov/fulltext/ED372945.pdf

Mihajlović, A. \& Dejić, M. (2015). Using Open-Ended Problems And Problem Posing Activities In Elementary Mathematics Classroom. https://www.researchgate.net/profile/Aleksandra_Mihajlovic/publicat ion/281784980_USING_OPEN-

ENDED_PROBLEMS_AND_PROBLEM_POSING_ACTIVITIES_ IN_ELEMENTARY_MATHEMATICS_CLASSROOM/links/55f88 39c08ae07629dd7f939/USING-OPEN-ENDED-PROBLEMS-ANDPROBLEM-POSING-ACTIVITIES-IN-ELEMENTARYMATHEMATICS-CLASSROOM.pdf

Moyer, P. S., \& Milewicz, E. (2002). Learning to question: Categories of questioning used by preservice teachers during diagnostic mathematics interviews. Journal of Mathematics Teacher Education, 5(4), 293-315. https://doi.org/10.1023/A:1021251912775 Muhtadi, D., Kartasasmita, B. G., \& Prahmana, R. C. I. (2017). The Integration of technology in teaching mathematics. In Journal of Physics: Conference Series, 943(1), 12-20.

https://iopscience.iop.org/article/10.1088/17426596/943/1/012020/pdf.

Muir, T. (2009). Investigating teachers' use of questions in the mathematics classroom. International Group for the Psychology of Mathematics Education, 4, 161-168. http://ecite.utas.edu.au/60518

NCTM. (2000). Principles and Standards for school mathematics. Reston, VA: National Council of Teachers of Mathematics

Nohda, N. (2000). Teaching by open-approach method in Japanese mathematics classroom. Proceedings of the 24th Conference of the International Group for the Psychology of Mathematics Education. http://files.eric.ed.gov/fulltext/ED466736.pdf

Pehkonen, E. (1997). Use of Open-Ended Problems in Mathematics Classroom. Research Report 176. Finland: University of Helsinki. Pehkonen, E. (1999). Open-ended problems: A method for an educational change. International Symposium on Elementary Maths Teaching (SEMT 99), Charles University, Prague. http://szalonta.hu/mm/resources/task2/Pehkonen.pdf 
Pehkonen, E., \& Ejesbo, L. R. (2005). Levels of a teacher's listening when teaching open problems in mathematics. In [Proceedings of the twenty-sixth annual meeting of the] North American Chapter of the International Group for the Psychology of Mathematics Education, October 2004, Toronto, Ontario, Canada (pp. 871-877)

Rosli, R., Capraro, M. M., \& Capraro, R. M. (2014). The effects of problem posing on student mathematical learning: A metaanalysis. International Education Studies, 7(13), 227. https://doi.org/10.5539/ies.v7n13p227

Savenye, W. C., \& Robinson, R. S. (1996). Qualitative research issues and methods: An introduction for educational technologists. Handbook of research for educational communications and technology, 1171-1195 https://doi.org/10.1111/00267902.00096

Schukajlow, S., \& Krug, A. (2014). Do multiple solutions matter?

Prompting multiple solutions, interest, competence, and autonomy. Journal for Research in Mathematics Education, 45(4), 497-533. https://doi.org/10.5951/jresematheduc.45.4.0497

Schuster, L., \& Anderson, N. C. (2005). Good Questions for math teaching: Why ask them and what to ask. Grades 5-8 Math Solutions, Sausalito, CA

Shahrill, M. (2013). Review of teacher questioning in mathematics classrooms. International Journal of Humanities and Social Science, 3(17), 224-231.

http://www.ijhssnet.com/journals/Vol_3_No_17_September_2013/23 .pdf

Smith, F., Hardman, F., \& Higgins, S. (2006). The impact of interactive whiteboards on teacher-pupil interaction in the National Literacy and Numeracy Strategies. British educational research journal, 32(3), 443-457. https://www.jstor.org/stable/30032677

Smith, H., \& Higgins, S. (2006). Opening classroom interaction: the importance of feedback. Cambridge journal of education, 36(4), 485502. https://doi.org/10.1080/03057640601048357

Sullivan, P., \& Lilburn, P. (2002). Good questions for math teaching: Why ask them and what to ask. Math Solutions Publications: US.

Sullivan, P., Warren, E., \& White, P. (2000). Students' responses to content specific open-ended mathematical tasks. Mathematics education research journal, 12(1), 2-17. https://doi.org/10.1007/BF03217071 
Tanner, H., Jones, S., Kennewell, S., \& Beauchamp, G. (2005). Interactive whole class teaching and interactive white boards. In Building connections: Research, theory and practice, Proceedings of the 28th annual conference of the Mathematics Education Research Group of Australasia (pp. 720-727).

https://citeseerx.ist.psu.edu/viewdoc/download?doi=10.1.1.586.5411 $\&$ rep $=$ rep $1 \&$ type $=$ pdf

Tofade, T., Elsner, J., \& Haines, S. T. (2013). Best practice strategies for effective use of questions as a teaching tool. American journal of pharmaceutical education, 77(7), 155.

https://doi.org/10.5688/ajpe777155

Wells, G. (1999) Dialogic inquiry towards a sociocultural practice and theory of education. Cambridge: Cambridge University Press.

Yee, F. Y. (2002). Using short open-ended mathematics questions to promote thinking and understanding. Singapore: NIE. http://math.unipa.it/ grim/SiFoong.PDF

Mela Aziza is a lecturer in department of Tadris Matematika, Faculty of Tarbiyah dan Tadris, Institut Agama Islam Negeri Bengkulu, Indonesia

Contact Address: Mela Aziza, Institut Agama Islam Negeri Bengkulu, Faculty of Tarbiyah dan Tadris, Jalan Raden Fatah, Kelurahan Pagar Dewa, Kecamatan Selebar, Bengkulu City, Bengkulu, 65144, Indonesia. Email: mela.aziza@iainbengkulu.ac.id 